\title{
Research on the Construction of Inclusive Innovation Networks
}

\author{
Wu Zhao, Ting Xiao, Anqi Wang* \\ School of Economics and Management, Xidian University, Xi'an Shaanxi \\ Email: ^2218506351@qq.com
}

How to cite this paper: Zhao, W., Xiao, T. and Wang, A.Q. (2018) Research on the Construction of Inclusive Innovation Networks. American Journal of Industrial and Business Management, 8, 417-431. https://doi.org/10.4236/ajibm.2018.82027

Received: February 1, 2018

Accepted: February 25, 2018

Published: February 28, 2018

Copyright $\odot 2018$ by authors and Scientific Research Publishing Inc. This work is licensed under the Creative Commons Attribution International License (CC BY 4.0).

http://creativecommons.org/licenses/by/4.0/

\begin{abstract}
Shared value creation concept emphasizes the future development of the enterprise to meet the needs of society into the core activities, create economic value by solving social problems, and make the bottom of the pyramid of low-income groups (BOP) markets for the practice of the concept and provide a comfortable environment. Based on six cases of enterprises operating in China's rural market, this paper discusses how enterprises can achieve economic returns and create social value strategies and approaches at the same time. Results show that because the BOP market is empty obstacles, such as lack of value chain and the system, enterprises need to build the heterogeneity of organization, institutions and individuals inter-departmental cooperation network to overcome, in the end by connecting two ways to enhance the capacity and promote local market shared value creation.
\end{abstract}

\section{Keywords}

Innovative Networks, The Bottom Market of The Pyramid, Network Governance

\section{Introduction}

In recent years, a large number of companies began to focus on its social and environmental impact of business practices, but the effect is not significant. The reason is that traditional economics believes that only by sacrificing the interests of enterprises in order to obtain social benefits, will enterprises to solve social and environmental issues increase the additional costs, so companies will not give it an important position. According to the above phenomenon, Porter and Kramer put forward shared value creation (CSV) under Creating Shared Value concept, pointing out that the enterprise's future development direction is to solve the social problems into the core issues of business strategy [1], including 
long-term poverty for the sustainable development of human society. In fact, Prahalad and Hart put forward the strategy of the pyramid (BOP) under Base of the Pyramid. The underlying strategy of the pyramid also proposed that low-income people contain huge wealth, and that enterprises can make profits through business innovation while reducing the poverty of the BOP group [2].

Based on the understanding of business and society, scholars put forward the CSV strategy. The traditional concept argues that social value will damage to enterprise profitability. The CSV strategy thinks that business progress will promote business progress, and the two will promote each other [3].

Therefore, CSV is first expressed as the creation of both economic and social values, and the creation of social value is the premise of creating economic value rather than the latter. Second, CSV is consistent with the overall strategy of the enterprise, mainly through the business innovation and implementation, enterprise core resources capabilities rather than social responsibility or charitable donations. The latter is a lot of the time pressure from the outside world and focuses on reputation for [4]. Finally, CSV does not share value by means of redistribution, but expands the value of economy and society.

Then we can discuss about the ways and means of sharing value creation. Avista combined with the company's practice that the opportunity of CSV comes from the matching of social needs [5], business opportunities and enterprise resources and professional skills [6]. And CSV is the key to find solutions to social problems and promote the intersection of economic progress, mainly focused on those traditionally considered the realm of market failure. Enterprises need to know constraints of using new technology, operation methods and management means to overcome [7]. Specifically, the following three methods are included:

1) To re-conceive products and markets.

2) By assessing the social impact of different activities in the value chain to adjust resource use, procurement, logistics, channels and site selection to reshape productivity.

3) To promote the development of local industrial clusters, and work together with the organizations and individuals in the region to build a business ecosystem.

Although the concept of CSV is widely accepted, how to translate it into practical action still lacks clear framework and tools, and the key is to measure the performance of CSV. Pfitzer argues that, if the enterprise through social performance improvement will not be able to measure the degree of economic performance, it will not be able to understand the relationship between social and business results, including four steps of measurement framework [8]:

1) To identify social problems.

2) To build a business plan.

3) To track progress.

4) To Measure results and release new value. 
To get a better understanding of the above process, Bockstette and Stamp (2012) explained ten modules of CSV, including strategy, goals, assets, management efforts and key partners [10].

Proposed BOP strategy. Worldwide, more than 4 billion people live in according to the wealth and income ability of the underlying economic pyramid, excluded from formal market system for a long time, never enjoyed the benefits of global economic growth, but as well as the deterioration of environment and social decay [11]. In the traditional business logic, the enterprise with the $80 \%$ of $80 \%$ of its revenue from high-income customers pare to principle, so rarely will the resources invested in low-income groups, to effectively meet the needs of the poor has never been. But for management C.K. Prahalad is acutely aware of the poor and the areas not subject of help but there is a huge potential market of commercial value, if the company can overcome the traditional prejudice, through technical and business model innovation to open up the BOP market, will be able to obtain economic returns and a new growth opportunities, also can improve the living standards of the poor or the production ability, create social value [12]. This kind of thinking and method to intervene poverty management with commercial innovation challenges the traditional view that only the government has the motivation and ability to deal with the problem of poverty, which is called the BOP strategy.

BOP strategy is essentially for the enterprise by way of market mechanism and the poor, and other stakeholders to create new value, there are both consumers and producers in the concrete implementation guide, corresponding to the poor in different roles and positioning in the market [13]. The poor in the early period of the BOP strategy research mainly regarded as valuable customers, think that although individual income level is very low and the poor, but because of its size, but the entire group representing the released sooner or later the huge purchasing power, so focus on discuss how companies to provide suitable for the new price of the BOP market [14]. But Karnani points out that for the poor, the lack of income is much higher than the restrictions the lack of a market to provide a variety of products and services, only increase the real income of the poor can really alleviate poverty. Consequently, subsequent studies have increasingly emphasized that the poor are producers and providers of resources and capabilities. Producer-oriented BOP strategies require companies to use or buy resources or outputs from the poor rather than selling to the poor [15]. But as a producer of the poor on the one hand, it is difficult to obtain high quality raw materials, capital and other resources, at the same time in the market to enter, maintain, market power and get security trading also faces many obstacles, through innovative mode and means to overcome these barriers will become critical to the success of the strategy of BOP [16].

Overall, the purpose of this article is to understand the building process of an inclusive, innovative network. Through case analysis, I found the existence of the BOP market, the lack of value chain and the system is missing. Businesses need cross-departmental collaboration between organizations, institutions and 
individuals to overcome existing problems, in the end by connecting two ways to enhance the capacity and promote local market Shared value creation.

\section{Methodology}

In this paper, we focused on Innovative networks. Case study as a standard academic research methods, contains a set of complete and unique design, logic, data gathering and analysis strategy, especially suitable for the understanding of the phenomenon and explore the "how" and "why" the nature of the problem [17], can also be applied to new or existing inadequate research field. This paper discusses the strategy and path of "how" to realize CSV in BOP market, so it is beneficial to construct the theory by using multiple case study methods.

The sample selection of case study is based on theoretical sampling rather than statistical sampling, and the selection criterion is based on the particularity of the case rather than the generality, namely the so-called "exploratory logic". From a number of cases, Eisenhardt that the number of cases in many case studies, four and eight in the most appropriate [18], Yin that case number with 6 10 advisable. According to the above principles, six agricultural enterprises are selected as the research samples, and the basic information is shown in Table 1. The main basis is [19]:

1) The enterprise type is taken into account, including state-owned enterprises, private enterprises and foreign-funded enterprises, etc.

2) The poor, as producers, provide resources such as human and social capital.

3) Sample enterprises have created good economic and social value.

4) Industry and regional balance.

To improve the case study of the reliability and validity, this study according to Miles and Huber man described by the triangulation method, collecting data from multiple sources Each enterprise mainly by field observation and semi-structured

Table 1. Basic situation of case enterprise.

\begin{tabular}{|c|c|c|c|c|}
\hline Enterprise name & Case & Core of BOP business & Type of enterprise & $\begin{array}{l}\text { Geographical } \\
\text { position }\end{array}$ \\
\hline $\begin{array}{l}\text { Hunan shunhua duck } \\
\text { company. }\end{array}$ & Linwu duck & $\begin{array}{l}\text { The breeding and } \\
\text { processing of linwu duck. }\end{array}$ & $\begin{array}{l}\text { State-owned private } \\
\text { joint ventures }\end{array}$ & e Hunan Chenzhor \\
\hline $\begin{array}{l}\text { New hope dairy } \\
\text { holdings limited. }\end{array}$ & New hope & $\begin{array}{l}\text { Dairy farming and dairy } \\
\text { products }\end{array}$ & & $\begin{array}{l}\text { Chengdu, Si- } \\
\text { chuan province }\end{array}$ \\
\hline $\begin{array}{l}\text { Nanjing jiukang } \\
\text { biotechnology co. } \\
\text { LTD. }\end{array}$ & $\begin{array}{l}\text { Nine, neem } \\
\text { Neem. } \\
\text { State-owned }\end{array}$ & $\begin{array}{l}\text { tree processing biological } \\
\text { pesticide }\end{array}$ & $\begin{array}{l}\text { private joint } \\
\text { ventures }\end{array}$ & $\begin{array}{l}\text { Nanjing, Jiangsu } \\
\text { province }\end{array}$ \\
\hline $\begin{array}{l}\text { Shandong shouguang } \\
\text { vegetable industry } \\
\text { group. }\end{array}$ & $\begin{array}{c}\text { Shouguang } \\
\text { vegetable } \\
\text { Organic }\end{array}$ & $\begin{array}{l}\text { vegetable planting and } \\
\text { processing. }\end{array}$ & $\begin{array}{c}\text { State-owned } \\
\text { enterprises (soes) }\end{array}$ & $\begin{array}{l}\text { Shandong } \\
\text { shouguang }\end{array}$ \\
\hline $\begin{array}{l}\text { Cofco Great Wall wine } \\
\text { co. LTD. }\end{array}$ & $\begin{array}{l}\text { Great Wall } \\
\text { wine }\end{array}$ & $\begin{array}{l}\text { Grape planting and wine } \\
\text { making. }\end{array}$ & $\begin{array}{c}\text { State-owned } \\
\text { enterprises (soes) }\end{array}$ & Hebei shore \\
\hline $\begin{array}{l}\text { PepsiCo foods (China) } \\
\text { co. LTD. }\end{array}$ & $\begin{array}{l}\text { PepsiCo } \\
\text { potato }\end{array}$ & $\begin{array}{l}\text { Processing and planting } \\
\text { of potatoes. }\end{array}$ & $\begin{array}{l}\text { The foreign capital } \\
\text { enterprise }\end{array}$ & $\begin{array}{c}\text { Inner Mongolia } \\
\text { dalat flag. }\end{array}$ \\
\hline
\end{tabular}


interview way to collect data, interview object include: enterprise top managers, BOP project executive, BOP producers, government officials, associations, financial institutions, head of the personnel and technical personnel, and so on, interviews and field research have three team members [20]. In addition to the first-hand information, it also has extensive collection of secondary data including enterprise documents, news reports and industry reports. During the data collection process, the team members reviewed the enterprise data repeatedly to ensure that all case studies had consistent structure and quality.

On the concrete analysis strategy, this study first to each case as an independent subject in-depth analysis, find out the sample enterprises in BOP markets of the main strategy and characteristics of commercial operations and detailed description, purpose is to have as much knowledge of case details, found that each case contains the specific content., in turn, follow the same research theme, cross case analysis for all case classification framework is established between case, will be a large amount of data under different categories are summarized and compared, find out the commonness and difference between case, the final research conclusion.

\section{Inclusive Innovation Networks}

Through the comparative analysis of the case, summing up the logic of enterprise in the BOP market to realize the CSV framework as shown in Figure 1, its core is to establish a cross-department cooperation network (hereinafter referred to as BOP under network) to overcome the BOP market. There are obstacles, which in turn promote local capabilities and promote markets. A logical framework for shared value creation is within the BOP market.

Connect two ways to achieve Shared value creation.

\subsection{Types and Characteristics of BOP Market Barriers}

Because of the BOP market environment and the high-end market in the main body, the foundation of the system and facilities conditions, differences exist, will produce many obstacles and constraints, can be classified into two categories, one is lack of value chain and the second, the system is empty.

First, many in the high-end market in the prevalence of suppliers, distributors, and qualified financial intermediaries and other professional market participants and supporting facilities in the BOP market does not exist, so the lack of the corresponding link needed to complete the value creation, low degree of specialization, the value chain. This allows BOP producers to have a lot of resources

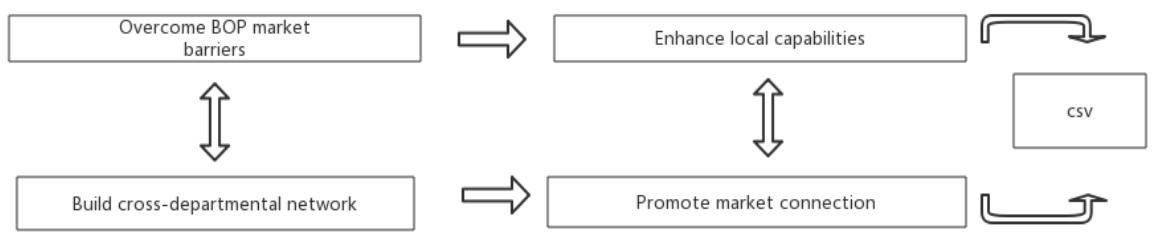

Figure 1. A logical framework for Shared value creation within the BOP market. 
(including natural endowments and long-term accumulated human capital) that are not supported by technology and capital and are idle or inefficient. In this paper, six cases, BOP producer before enterprises involved in varying degrees, in a discrete state of small business, cannot bring resources endowment through value chain into high value-added output. For example, in Xiangnan and northern Guangdong province, Linwu duck enjoys a long reputation, but the farming and sales are mainly distributed among farmers, small scale and miscellaneous products. And in the case of the Shandong Shouguang vegetables, farmers grow vegetables in the traditional way, initially neither shed can grow vegetables all the year round, no technology can produce high value-added organic vegetables. In Hailai county, a lot of grape growers in the grapes mature later, because of the lack of specialized storage technology and the market intermediary organizations, cannot be sold quickly, grape had to be sold at very cheap price in the local, sometimes only rot in the field. Therefore, lack of value chain of the BOP producers to lock in small scope of their business, reduce the high value-added products and services in the BOP market development or the possibility of chance, especially as the formal market production specification and standard is higher and higher, the BOP producers of survival and competition ability has become increasingly weakened.

Secondly, it needs proper institutional arrangement to support the benign operation of market mechanism, such as clear information channel, clear property right definition, complete legal guarantee and effective implementation. But in BOP markets, the formal institutional arrangements are relatively weak and cannot play their role, so as to constitute a system of holes (Institutional Void) [21]. On the one hand, the institutional hole prevents BOP producers from becoming effective market participants and is excluded from many formal market activities. If they points out that the lack of legal definition of property right makes it hard for assets and capabilities of the poor have fully capitalized, almost can't through formal channels of access to basic services such as credit and guarantees [22], H. In this case, the savings and less collateral is not approved, most of the BOP producers of reimbursement ability by Banks and other credit institutions formal evaluation is very low, very little access to the funds needed for the production and operation, can only rely on family, neighborhood, such as local social network to get help, sometimes have to rely on informal financing channels such as usury. In addition, BOP producers are engaged in activities related to planting and breeding. The cycle is relatively long and sensitive to changes in external natural conditions. When extreme environments such as droughts, floods and outbreaks occur, crops will be damaged. For example, in the case of Pepsi potato, due to the abundant sunshine in the desert area, low soil organic matter content and poor water retention and fertilizer capacity, once the water shortage can seriously affect the potato harvest and quality. At the same time, the BOP producers are exposed livestock products market price fluctuations is bigger, often very difficult to stabilize prices to sell their products for a long time, such as huge fluctuations in vegetable prices have in Shandong Shou- 
guang vegetable farmers caused great losses, last season the price is a very good vegetable at this season but we cannot sell price, vegetable farmers is no way to avoid price fluctuations, it is hard to make reasonable choice to next quarter kinds of vegetables. However, in BOP market, there are few perfect insurance and subsidy system arrangements to eliminate or reduce the impact of these natural disasters and market fluctuations., on the other hand, because of China's BOP market is the basic geographical dispersion of rural areas, relatively closed "acquaintance society" characteristics and mistrust of the business into endogenous BOP groups, making deals largely confined to the local and rely on the approach of the geographical and social relationship between traders. It is very difficult to guarantee the conclusion and performance of the contract when the enterprise does not have the local legitimacy and the business operation according to the formal law and the market rules, which has a high transaction cost. As at the beginning of the shun China series company operation, many duck farmers for short-term gain will take some breeding, breach of contract terms and when the market price is higher than the contract price, will have secretly to bypass the company will sell duck, this kind of dispute is difficult to solve through formal legal channels. Therefore, the institutional hole leads to high uncertainty in the commercial production and trading of producers and enterprises in BOP market, which limits the space and stability of value creation.

\subsection{The Construction and Function of Interdepartmental Cooperative Network}

Because of lack of value chain and the hole system, enterprises need to complete a lot of other professional institutions, such as knowledge and skills help BOP producers, finance and investment in infrastructure construction, etc. However, this series of activities is too expensive for individual enterprises, and the externality of many activities also inhibits the direct investment of enterprises. Therefore, in the process of overcoming BOP market obstacle, establishing cooperative relationship with organizations, institutions and individuals in different fields becomes the natural selection of enterprises. In this paper, all case companies around the core business in BOP markets for the value of the network, through coordinated resources and capabilities to improve efficiency, reduce risk and create more value.

Firstly, the establishment and improvement of BOP network can fill the gap of value chain, and integrate BOP producers into the process and system of value creation more effectively. Table 2 shows the participants of BOP network in 6 cases and their roles and functions, which can be divided into three categories: drivers, supporters and regulators. Among them, the driver, including enterprise and the low income (producers), they are the BOP network formation driving force, the relationship between the two is the basis for the BOP network construction and operation; Supporters is to support the BOP derivative value creation organization with the functions of professional institutions, mainly provide venues, capital, technology and market information, to improve the efficiency 
Table 2. BOP network members and role functions.

\begin{tabular}{|c|c|c|c|}
\hline Enterprise & Role & $\begin{array}{l}\text { Members of the } \\
\text { network }\end{array}$ & Function \\
\hline \multirow[t]{8}{*}{$\begin{array}{l}\text { Linwu duck } \\
\text { company. }\end{array}$} & driver & The company & Production and marketing. \\
\hline & & BOP producers & Breeding duck. \\
\hline & supporters & Breeding company & $\begin{array}{l}\text { Specialized in incubation, breeding, } \\
\text { acquisition, technical training and other } \\
\text { activities with farmers. }\end{array}$ \\
\hline & & The farm & $\begin{array}{l}\text { The breeding of the ducks is diverted from } \\
\text { small-scale operations to large-scale farming. }\end{array}$ \\
\hline & & $\begin{array}{l}\text { Rural credit } \\
\text { cooperatives }\end{array}$ & $\begin{array}{l}\text { To provide loans to farmers under the } \\
\text { guarantee of the company to solve the shortage } \\
\text { of breeding funds. }\end{array}$ \\
\hline & & Technical experts & $\begin{array}{l}\text { Responsible for technical training, vaccine, } \\
\text { feeding and other technical support. }\end{array}$ \\
\hline & $\begin{array}{l}\text { The } \\
\text { compliance }\end{array}$ & $\begin{array}{l}\text { Aquaculture } \\
\text { association }\end{array}$ & $\begin{array}{l}\text { The company shall arrange production quantity } \\
\text { by contract with the company and distribute the } \\
\text { production tasks to the farmers, providing } \\
\text { information, dispensing funds, coordinating } \\
\text { production and assisting the transaction } \\
\text { negotiation and other services. }\end{array}$ \\
\hline & & The local governmen & $\begin{array}{l}\text { Provide financial support and subsidies } \\
\text { tand help farmers to establish risk } \\
\text { protection mechanism. }\end{array}$ \\
\hline \multirow[t]{5}{*}{ Nine, neem } & driver & The company & $\begin{array}{l}\text { Seed acquisition, } \\
\text { R \& d, production and marketing. }\end{array}$ \\
\hline & & $\mathrm{BOP}$ producers & $\begin{array}{l}\text { The land is leased to the company and is } \\
\text { recruited into the base for various jobs. }\end{array}$ \\
\hline & supporters & $\begin{array}{c}\text { Academy of } \\
\text { agricultural sciences' }\end{array}$ & $\begin{array}{l}\text { Assist the company in product research and } \\
\text { development and provide technical support. }\end{array}$ \\
\hline & & Seedling base & $\begin{array}{l}\text { Recruit some local personnel to carry out the } \\
\text { training for the base management, and further } \\
\text { recruit local farmers to be responsible for the } \\
\text { cultivation and cultivation of neem seedlings. }\end{array}$ \\
\hline & $\begin{array}{l}\text { The } \\
\text { compliance }\end{array}$ & The local governmen & $\begin{array}{l}\text { Provide fund subsidy, assist to establish } \\
\text { tproduction base, help expand the provincial and } \\
\text { overseas markets. }\end{array}$ \\
\hline \multirow[t]{4}{*}{ New hope dairy. } & driver & The company & Production and marketing. \\
\hline & & BOP producers & Dairy cows. \\
\hline & supporters & The cow plot & $\begin{array}{l}\text { Dairy cattle breeding area, the company } \\
\text { provides related equipment, after the } \\
\text { completion of the milk offset. }\end{array}$ \\
\hline & & The cooperative & $\begin{array}{l}\text { The powerful livestock farmers attract scattered } \\
\text { dairy farmers for intensive farming. }\end{array}$ \\
\hline \multirow[t]{2}{*}{$\begin{array}{l}\text { Shandong } \\
\text { shouguang } \\
\text { vegetable. }\end{array}$} & driver & The company & $\begin{array}{l}\text { Processing and marketing vegetables, actively } \\
\text { explore the international market. }\end{array}$ \\
\hline & & BOP producers & Responsible for vegetable planting. \\
\hline
\end{tabular}




\section{Continued}

\begin{tabular}{|c|c|c|c|}
\hline & supporters & $\begin{array}{c}\text { Cooperatives and } \\
\text { bases }\end{array}$ & $\begin{array}{l}\text { Responsible for the procurement of seeds, } \\
\text { pesticides, fertilizers and farm tools; To } \\
\text { supervise and supervise the daily field } \\
\text { management of vegetable fields. }\end{array}$ \\
\hline & & Technical experts & $\begin{array}{l}\text { To guide farmers to produce green vegetables } \\
\text { strictly according to international standards; } \\
\text { We will develop new varieties of vegetables and } \\
\text { promote new cultivation patterns and pest } \\
\text { control techniques. }\end{array}$ \\
\hline & & Sales agents & $\begin{array}{l}\text { Open up the foreign port market, develop } \\
\text { agricultural products direct selling business. }\end{array}$ \\
\hline & & $\begin{array}{l}\text { Agbank and credit } \\
\text { union. }\end{array}$ & Loan service. \\
\hline & $\begin{array}{l}\text { The } \\
\text { compliance }\end{array}$ & The local government & $\begin{array}{l}\text { New demonstration park, planning and } \\
\text { construction of agricultural high-tech corridor. }\end{array}$ \\
\hline \multirow[t]{7}{*}{ Great Wall wine } & driver & The company & Early investment, production and sales. \\
\hline & & BOP producers & Growing grapes. \\
\hline & supporters & Grape industry group & $\begin{array}{l}\text { Responsible for grape industry management, } \\
\text { organization and coordination, technical } \\
\text { service, seedling supply, etc. }\end{array}$ \\
\hline & & $\begin{array}{l}\text { Professional } \\
\text { cooperative }\end{array}$ & $\begin{array}{l}\text { Integrated vineyard formation scale, unified } \\
\text { management and standardized operation. }\end{array}$ \\
\hline & & Technical experts & $\begin{array}{l}\text { Unified seedling, unified standard, unified } \\
\text { water supply, unified technical service. }\end{array}$ \\
\hline & & Base & $\begin{array}{l}\text { Promote farmers to standardize cultivation, fine } \\
\text { management, standardized operation, increase } \\
\text { planting benefit. }\end{array}$ \\
\hline & $\begin{array}{l}\text { The } \\
\text { compliance }\end{array}$ & The local government & $\begin{array}{l}\text { Develop preferential policies to encourage } \\
\text { farmers to grow grapes. }\end{array}$ \\
\hline \multirow[t]{4}{*}{ PepsiCo potato } & driver & The company & $\begin{array}{l}\text { The early stage investment, production } \\
\text { processing and sales of the farm. }\end{array}$ \\
\hline & \multirow{3}{*}{ supporters } & BOP producers & $\begin{array}{l}\text { Planting potatoes, leveling sand dunes, } \\
\text { planting trees to prevent wind and sand, } \\
\text { and soil improvement. }\end{array}$ \\
\hline & & The farm & $\begin{array}{l}\text { Provide irrigation equipment and so on, } \\
\text { regulate seed breeding, field management, etc. }\end{array}$ \\
\hline & & $\begin{array}{c}\text { Academy of } \\
\text { agricultural sciences' }\end{array}$ & $\begin{array}{l}\text { Through the test tube seedling technology, } \\
\text { the introduction of American excellent } \\
\text { potato varieties. }\end{array}$ \\
\hline
\end{tabular}

of production and trade, such as base, financial institutions, research institutes and market intermediary organizations, etc.; The norm is the organization that helps form the rules and norms of transactions at the institutional level, including government departments, associations and local communities. 
Secondly, the construction and operation of BOP network can make up for the institutional hole formed by the absence of formal system, including the following three mechanisms of mutual cooperation and support. One is to enter into a formal contract, which is the precondition of running mode, provide network participants with the behavior of the basic norms and standards, including company and farmers employment and procurement contracts and more complex in agreement, etc.; Second, the use of local social capital. Despite the BOP area lack of mature business rules and market awareness, but contains a rich social norms and informal institutional elements such as customs, and local family, neighbors, friends and other relative and geographical relations has accumulated a lot of social capital, influence and the production and trade of People's Daily activities. When local members being incorporated into the BOP network, the informal institutional factors will have different levels of use, such as can be based on reputation and punishment mechanism to solve the information asymmetry in the trade and the enterprise is difficult to supervise the implementation. The third is to build up new social capital.BOP network construct and run itself, in fact, will establish a variety of contact between previously separate members, the parties will be on display in the interactive method and process of a negotiated solution to the problem a new trust relationship, take this to use these new building social capital to design a suitable institutional arrangement or business model, the BOP market efficiency and the effect of value creation.

Traditional financial institutions rarely reluctant to lend to the poor, for example, but in BOP networks, companies can provide guarantees for the BOP producers, while association or cooperation will select qualified applicants and through the internal constraints to supervise the use of funds, to a large extent solve the problem of adverse selection and moral hazard in lending. In the case of the ducks, the enterprise, aquaculture association and the government also negotiated the establishment of the "Linwu duck breeding insurance fund" to provide compensation for the farmers who suffered losses due to natural disasters, epidemics and accidents. All three of these mechanisms can be in network conditions to form a hybrid system arrangement, the core members more closely relates in together, is not only a simple market contractual relationship, also includes informal trust and mutually beneficial relationship, eventually formed in continuous trial and error and adjust the Shared norms, rules and agreements. But it should be pointed out that, although the enterprise is the core of the BOP network, but not to directly control the establishment and development of all relationships, more is by providing cooperation framework, communication mechanism and knowledge to guide the way to the role of the member functions. Relationship interwoven with different properties can form a kind of beneficial to CSV system environment, to make up for the deficiency of the formal system, and for the production and business activities within the BOP market support. Table 3 gives six cases to make up for the specific performance of the system. 
Table 3. System function of BOP network.

\begin{tabular}{|c|c|c|c|}
\hline Case & Enter into a formal contract & Use local social capital. & Build new social capital \\
\hline Linwu duck & $\begin{array}{l}\text { The enterprise and the farmer sign the purchase } \\
\text { agreement, through the village cadre and the } \\
\text { local prestige person to deal with the contract to } \\
\text { buy the duck quantity, the quality, the price and } \\
\text { the breeding technical index, etc. }\end{array}$ & $\begin{array}{l}\text { Contract disputes between the } \\
\text { company and the farmers; Use the } \\
\text { village committee to reduce the } \\
\text { management cost to farmers. }\end{array}$ & $\begin{array}{l}\text { The company and the association, the } \\
\text { rural credit union and the peasant } \\
\text { households have jointly established the } \\
\text { "quadrilateral insurance credit } \\
\text { mechanism" and "the military breeding } \\
\text { insurance fund" to protect the common } \\
\text { interests. }\end{array}$ \\
\hline Nine, neem. & $\begin{array}{l}\text { Enterprises and farmers sign agreements to } \\
\text { purchase prices; Use of local personnel to assist } \\
\text { in the implementation of the contract; }\end{array}$ & $\begin{array}{l}\text { Companies build roads for the } \\
\text { region; Locally trained local } \\
\text { personnel to undertake daily } \\
\text { management of the base. }\end{array}$ & $\begin{array}{l}\text { The weak labor force, such as women } \\
\text { and old people, alleviates household } \\
\text { stress. }\end{array}$ \\
\hline New hope dairy. & $\begin{array}{l}\text { Enterprises and dairy farmers sign "fresh milk } \\
\text { purchase and sale contract" and dynamically } \\
\text { increase the purchase price of fresh milk based } \\
\text { on market fluctuation. }\end{array}$ & $\begin{array}{l}\text { The use of some of the country's } \\
\text { well-funded livestock farmers will } \\
\text { scrap unused construction sites, } \\
\text { attracting many farmers to the } \\
\text { surrounding cattle. }\end{array}$ & $\begin{array}{l}\text { Introduce the dairy farming } \\
\text { community, and form a community of } \\
\text { interests with the farmers; } \\
\text { The government has jointly launched an } \\
\text { incentive policy to subsidize farmers' } \\
\text { purchase of dairy cows. }\end{array}$ \\
\hline $\begin{array}{l}\text { Shandong } \\
\text { shouguang } \\
\text { vegetable. }\end{array}$ & $\begin{array}{l}\text { Enterprises signed agreements with farmers to } \\
\text { buy high-value-added output such as green food } \\
\text { and vegetables. }\end{array}$ & $\begin{array}{l}\text { The local government has } \\
\text { eliminated the suspicion of farmers } \\
\text { joining cooperatives; Use local } \\
\text { technical staff to tour guides. }\end{array}$ & $\begin{array}{l}\text { The farmers will use the greenhouse as } \\
\text { the asset to buy into the cooperative, the } \\
\text { establishment of various professional } \\
\text { associations; We will establish a platform } \\
\text { for agricultural trust and strengthen } \\
\text { interaction. }\end{array}$ \\
\hline Great Wall wine & $\begin{array}{l}\text { Contract with farmers to determine the quantity } \\
\text { and quality of grape acquisitions. }\end{array}$ & $\begin{array}{l}\text { Use local government departments } \\
\text { to encourage farmers to grow } \\
\text { grapes; Develop local farmers as } \\
\text { grape brokers. }\end{array}$ & $\begin{array}{l}\text { Farmers have taken stakes in } \\
\text { cooperatives, such as land and capital, to } \\
\text { form a growing union; Establish good } \\
\text { cooperation with local government. }\end{array}$ \\
\hline PepsiCo potato & $\begin{array}{l}\text { The company buys potatoes according to the } \\
\text { contract, taking into account the interests of the } \\
\text { company and the farmers. }\end{array}$ & $\begin{array}{l}\text { Use local agronomists to train and } \\
\text { guide farmers to standardize their } \\
\text { planting. }\end{array}$ & $\begin{array}{l}\text { Businesses build roads, wire lines and } \\
\text { introduce sprinklers, thriving } \\
\text { communities. }\end{array}$ \\
\hline
\end{tabular}

\section{Inclusive Innovation Networks Achieve Shared Value Creation}

First of all, the local ability refers to the BOP area of natural resource endowment, infrastructure, human and social capital, enterprise after entering the BOP market, to these resources endowment for effective identification and evaluation, and then through the BOP network construction and improve and promote its value creation ability. The ascension is mainly through the interconnected implementation in three ways: one is direct investment to improve the BOP market infrastructure and land development, such as the Jiu Kang company built through seedling base road, improve the local transportation facilities. The second is to combine new resources with local resource endowments to create higher value, such as using high quality raw materials, capital and technology. In the case of PepsiCo, farmers used the American "Atlantic" variety to make a big difference in the shape, eye, sugar and solid content of potatoes. The third is to use the innovation of organizational model to coordinate and summarize the discrete resource capacity, so that the value of the whole creation is far greater 
than the sum of the individual creation value. Such as in Shandong Shouguang, $80 \%$ of farmers through cooperatives into fruit and vegetable industrialization system, "company + cooperative + peasant household" mode enable farmers generally realize large-scale production and sales of plant, specialized production and organization management.

Second, to promote the market connection refers to the enterprises and other members of the network operations in the BOP market will gradually get rid of the poor rejection in the formal market outside of the various constraint conditions, promote the BOP market exchanges and interaction with other markets, thereby the BOP community and population into a wider market and social network. On the one hand, by connecting with other markets, BOP local products and services can achieve higher value in a larger market. Such as Shandong Shouguang vegetable group's products are exported to Europe, Japan, South Korea, Hong Kong, connection and interaction of the different levels the market has led the local industrial upgrading, benefit more people BOP. On the other hand, market connections also enlarge the opportunity space of BOP market, reduce the market access restriction and enhance the market power of $\mathrm{BOP}$ producers. For a long time, on the edge of the BOP producers as small and market participants, both the lack of close to the end market channels directly, also cannot timely access to market information, always at a disadvantage position in the negotiation and trading. But connection degree of deepening, as the market more transparent and rapid information flows, BOP producers more market awareness and accumulated new bridge of social capital, the original region closed form of asymmetric information and power status will be eased significantly. Especially the BOP network members of the respective resource capacity are different, to give full play to their comparative advantages, enterprises tend to assign part of the network to motivate BOP power producers, improve the overall quality and efficiency. For example, in the case of duck, the organization and management of farmers are mainly borne by the farmers' self-established aquaculture association in order to concentrate on developing products and developing markets. As the company's market range from Linwu county extension to even state in Guangdong, Chenzhou, Hunan, appropriate chapter, Guiyang and Ningyuan, aquaculture association has been expanding and growing and mutual connection, can price, capital, technology and policy aspects of consultation with companies and government departments, the protection of the rights of the BOP producers.

Anyhow, BOP network build hole through lack of value chain and the system can overcome obstacles, such as promoting the development of the BOP market system and perfect, thus effectively improved the ability of local BOP market and promote the connection with the external market, this not only opens up a new market and product, and to redefine the value chain of the productive forces, also promoted the development of local industry cluster, is in line with the Porter, etc. are discussed with the results in the path to the CSV. 


\section{Conclusions}

CSV represents a concept of promoting the advancement of business and social coordination development. The core is the enterprise to obtain economic returns to create social value. The bottom for the practice of the concept provides a good market environment. This article, based on the analysis and comparison of six cases of enterprises, found that the BOP market has many restrictions on the obstruction of value creation, in addition to itself, which has more than the poor dispersion and low production skills, including the lack of professional intermediary service organization and market organization value chain vacancy caused by the imperfect system and formal system hole problem. In order to overcome these obstacles, the enterprise will promote the construction of cross-sectoral cooperation network, in the original decentralized organization, institutions and individuals to establish various forms of commercial and non-commercial, which on the one hand, can put the different members of the resources allocation and integration to compensate for the missing link in the process of value creation within the BOP market, improve the ability and the consciousness of the BOP producers, and form a contract between members of the network and trust of mixed trading system of governance mode to fill the empty. BOP network running will continue to improve the ability of local BOP area, and at the same time promote the flow of information, knowledge and resources in the market and the connection with the external market, and finally realizes the creation of shared value.

At the practice level, considering the BOP problems under the environment of informal institutional factors, it is not only limited to the business, but it also wants to pay attention to social connections and political connection, which requires enterprises to develop with heterogeneity organizations to interact, learn and consult network capacity. Due to the special BOP environment in China, the government, not western NGO, is one of the important partners. Enterprises can rely on good relations with the government, which is an important condition to success in the BOP market. And from the angle of the government, the business activities of enterprises in the BOP market should be open to help enterprises build efficient operation of the BOP network, such as giving legitimacy, conflict resolution, and providing technical support, etc., but also to supervise the behavior of the enterprises and other members of the network, so as to avoid BOP producers due to the information and ability deficiency of hurt.

\section{Funding Project}

Shaanxi Province soft science research project (2017KRM064); Shaanxi Provincial Social Science Fund Project (2016R035); Xi'an soft science project (2016044SF/RK07-(2)); Xi'an Social Science Planning Fund Project (17J69).

\section{References}

[1] Porter, M.E. and Kramer, M.R. (2011) Creating Shared Values: How to Reinvent 
Capitalism and Unleash a Wave of Innovation and Growth. Harvard Business Review, No. 1, 1-5.

[2] Prahalad, C.K. and Hart, S.L. (2002) The Fortune at the Bottom of the Pyramid. Strategy and Business, No. 26, 54-67.

[3] Schmitt, J. (2014) Understanding Shared Value. Springer Fachmeelien, Wiesbaden, 19-30.

[4] Porter, M.E. and Kramer, M.R. (2006) The Link between Competitive Advantage and Corporate Social Responsibility. Harvard Business Review, No. 12, 1-13.

[5] Avista. (2011) Building Shared Value for a Shared Future. Spokane, 1-3.

[6] Pfitzer, M., Bockstette, V. and Stamp, M. (2013) Innovating for Shared Value. Harvard Business Review, No. 9.

[7] Porter, M.E., Hills, G. and Pfitzer, M. (2012) Measuring Shared Value: How to Unlock Value by Lining Social and Business Results. Foundation Strategy Group, No. 3, 100-107.

[8] Bockstette,V. and Stamp, M. (2011) Creating Shared Value: A How-to Guide for the New Corporate Revolution. Foundation Strategy Group, No. 3, 12.

[9] Winder, K.L., Rose, J.A. and Viswanathan, M. (2009) Marketing to Subsistence Consumers: Lessons from Practice. Journal of Business Research, No. 6, 559-659.

[10] Prahalad, C.K. (2005) The Fortune at the Bottom of the Pyramid. Wharton School Publishing, Philadelphia, 1-12.

[11] Quinn. J.B. (1992) Intelligent Enterprise: A Knowledge and Service Based Paradigm for Industry. Management Accounting, No. 3, 109.

[12] Chikweche, T. and Richard, F. (2010) Understanding Factors That Influence Purchase in Subsistence Markets. Journal of Business Research, 63, 643-650. https://doi.org/10.1016/j.jbusres.2009.04.024

[13] Karnani, A.G. (2007) The Mirage of Marketing to the Bottom of the Pyramid: How the Private Sector Help Alleviate Poverty. California Management Review, No. 6, 582-584.

[14] London, T., Anupindi, R. and Sheth, S. (2010) Creating Mutual Value: Lessons Learned from Ventures Serving Base of the Pyramid Producers. Journal of Business Research, No. 6, 1-8.

[15] Christiansen, N. (2014) Business Initiatives that Overcome Rural Poverty and Marginality through Creating Shared and Value. Springer, Netherlands, 2-3.

[16] Mendoza, R.U. and Thelen, N. (2008) Innovations to Make Markets More Inclusive for the Poor. Development Policy Review, 26, 427-458.

[17] Yin, R.K. (2009) Case Study Research: Design and Methods. 4th Edition, Sage Publications, Thousand Oaks, 240.

[18] EiSenhardt, K.M. (1989) Buildings Theories from Case Study Research. Academy of Management Review, 14, 532-550.

[19] Yin, R.K. (2002) Applications of Case Study Research. Stage Publications, Thousand Oaks, 22-28.

[20] Miles, M.B. and Huberman, M. (1994) Qualitative Data Analyse: An Expanded Sourcebook. Sage Publications, Thousand Oaks, 58-68.

[21] Mair, J. and Mart, I. (2009) Entrepreneurship in and around Institutional Voids: A Case Study from Bangladesh. Journal of Business Venturing, 24, 419-435. 
https://doi.org/10.1016/j.jbusvent.2008.04.006

[22] Desoto, H. (2000) The Mystery of Capital: Why Capitalism Triumphs in the West and Fails Everywhere Else. Basic Books, New York, 8-16. 